\title{
Pequi pulp oil: effect on the physicochemical, nutritional, and textural properties of cottage cheese
}

\author{
Otília Monica Alves BORGES ${ }^{1}$, Ídila Maria da Silva ARAÚJO², Kirley Marques CANUTO², \\ Juliane Döering Gasparin CARVALHO ${ }^{1}$, Hilton César Rodrigues MAGALHÃES ${ }^{2}$, \\ Tigressa Helena Soares RODRIGUES ${ }^{3}$, José Osvaldo Beserra CARIOCA ${ }^{1}$, Socorro Vanesca Frota GABAN ${ }^{1 *}$
}

\begin{abstract}
The present study aimed to produce a new cheese added with pequi (Caryocar coriaceum) pulp oil. In total, 11 formulations, prepared according to the Central Composite Rotatable Design, with two independent variables (pequi pulp oil and emulsifier) and two levels ( 7 and 13\%; 1 and 2\%) were assessed for moisture, protein, lipids, $\mathrm{pH}$, acidity, color, and texture. In conclusion, pequi pulp oil and emulsifier improved the texture and body of the cheese by decreasing its cohesiveness, hardness, gumminess, springiness, and chewiness.
\end{abstract}

Keywords: fatty acid; cheese; chemical composition; texture.

Practical Application: Development of a healthy cheese.

\section{Introduction}

The current interests of the food industry are focused on the development of low-fat products, as excessive consumption of saturated fatty acids has been associated with increased health problems such as coronary heart disease, hypertension, obesity, and diabetes. Thus, development of novel functional foods that contain health-promoting ingredients is a mandatory challenge for the food industry (Castillo et al., 2018). Dairy industry represents an important sector of the global food system. As reported by the Food and Agriculture Organization (2019), there was an increase in milk production by $1.6 \%$ in the year 2018 . It also estimated an annual growth of $1.7 \%$ in milk production till 2028. More than 6 billion people worldwide consume milk and milk products. The global market is dominated by the milk segment, followed closely by those of butter and cheese. According to Research and Markets, the global cheese market is expected to be around USD 112.8 billion by the year 2025 (Wood, 2020). The growing demand for dairy products is due to an increase in income and change in the dietary preferences of the people (Food and Agriculture Organization, 2019). Milk and milk products are sources of proteins, essential minerals (calcium, potassium, magnesium, sodium, phosphorus, and iodine), fat-soluble vitamins (A, D, E, and $\mathrm{K}$ ) and vitamin $\mathrm{B}$ (B1, B3, B6, and B12) (Górska-Warsewicz et al., 2019).

An innovation within the dairy sector is the production of cheese analogues, which are defined as cheese-like products produced by the replacement of one or more milk components, in particular milk fat, by non-milk-based components (Aini et al., 2020). The use of edible oils rich in unsaturated fats is promising for reducing the cholesterol content of cheese, while increasing levels of unsaturated fatty acids, which are known to confer cardioprotective effects (Al-Ismail et al., 2015). Studies have shown that among edible oils, it is possible to use palm, canola, virgin coconut, olive, corn, and sesame oil in cheese processing (Lobato-Calleros et al., 2007; Al-Ismail et al., 2015; Aini et al., 2020; Bielecka \& Cichosz, 2020).

Cottage cheese is a type of cheese that has increased interest from consumers who expect to obtain food health benefits due to its low-fat content and nutritional value. It is a soft fresh cheese, white in color, with a mild flavor, unripened, particulate, made by coagulating skim milk by the addition of lactic acid. It is usually mixed with a cream dressing to increases its smoothness (Rasheed et al., 2016). Moreover, cream dressing is used to adjust the final fat content from 1 to $4 \%$, and comprises cream, whole milk, stabilizers (gums, starches, emulsifiers, and phosphates), cultured milk, and salt (Rasheed et al., 2016).

Caryocar coriaceum Wittm. (Caryocaraceae) is a common tree found in the savannah area of Brazilian Northeast, also known as cerrado. Its fruit, popularly known as "pequi" or "piqui" is considered as a "symbol of the cerrado" and is currently undergoing an expansion process. In the past, the fruit had no economic value as it was being consumed only by the producing regions and never exported outside (Silva \& Fonseca, 2016). However, the development of new techniques for fruit preservation by the industries, made it possible to consume the fruit throughout the year in other regions, and even to export it to other countries such as the United States, Japan, and European countries. The industries produce and commercialize the whole fruit, pulp, chestnut, and the pequi cream. This has led to the emergence of a true pequi production chain, which has expanded to 
other derivatives such as flour, oil, liquor, candy, biscuits, and even pequi ice cream (Silva et al., 2020; Guedes et al., 2017). Its fruit provides nutritional oil, which is generally extracted from the almond or pulp. Its oil is a rich source of carotenoids, phenolic compounds, and unsaturated fat acids (Lima et al., 2020). These compounds may be responsible for some of the functional properties reported for pequi oil such as antioxidant and antibacterial activities (Vale et al., 2019; Pereira et al., 2020).

Considering that pequi oil is rich in unsaturated fatty acids as well as bioactive compounds, the present study aimed to develop new healthy cheese containing pequi oil. An idea to create an innovative product by incorporating pequi oil to a specific type of cheese, not only brings a new healthy food proposal to the consumers but merges the two expanding sectors namely, the dairy industry and the production of pequi fruit.

\section{Materials and methods}

\subsection{Pequi pulp oil extraction}

The homemade method of obtaining the edible pequi oil has been previously described by Figueiredo et al. (2016). Pequi fruits were collected in the city of Barbalha, Ceará. Pequi fruits (putamen) were then placed in boiling water $\left(100^{\circ} \mathrm{C}\right)$ for 40 minutes. During this process, the oil separated from the pulp and floated to the surface, and was collected with a spoon. In total, 300 fruits weighing $33.2 \mathrm{~kg}$ yielded $4.7 \mathrm{~kg}$ of pulp and 1 liter of oil.

\subsection{Physiochemical analysis of pequi pulp oil}

Densities of oil were measured using an R.D bottle. Acid value, peroxide value, and saponification value were determined according to the AOAC (Association of Official Analytical Chemists, 1999). The iodine value was determined using the method described by IUPAC (International Union of Pure and Applied Chemistry, 1979).

\subsection{Analysis of pequi oil by gas chromatography coupled to mass spectrometry}

Transesterification of fatty acids was performed according to the AOAC (Association of Official Analytical Chemists,
1999). The pequi oil was subjected to GC-MS analysis on an Agilent 7890/5977 quadrupole GC-MS instrument (Agilent Technologies, CA, USA), equipped with a HP-5MS polymethylsiloxane column $(30 \mathrm{~mm} \times 0.25 \mathrm{~mm} \times 0.25 \mu \mathrm{m}$; J \& W Scientific Inc., Folsom, USA). The samples were injected at a split ratio of 1:50. Chromatographic oven programming: initial temperature of $35^{\circ} \mathrm{C}$, with heating ramp of $15^{\circ} \mathrm{C} \mathrm{min}{ }^{-1}$ to $180^{\circ} \mathrm{C}$ and increment of $5^{\circ} \mathrm{C} \mathrm{min}$ m $^{-1}$ to $250{ }^{\circ} \mathrm{C}$ and remained for $10 \mathrm{~min}$ to the end of the run. The injector and quadrupole were set at $250{ }^{\circ} \mathrm{C}$ and $150{ }^{\circ} \mathrm{C}$, respectively. Compounds were identified by analysis of MS fragmentation patterns and were confirmed by matching their mass spectra with those from the database (NIST 2.0- 287,324 compounds) and by comparing their retention index (determined by injection of the mixture of a homologous series of C7-C30 alkanes, with literature data (NIST Chemistry Webbook, 2011; Adams, 2007). The fatty acid (FA) composition in percentage ( $\mathrm{g} 100 \mathrm{~g}^{-1} \mathrm{FA}$ ) was based upon the relative percentage of the total peak area.

\subsection{Experimental design of cottage cheese added with pequi pulp oil}

In total, 11 formulations, including four factorial points, four axial points, and three replicated center points for statistical assessment of the pure error sum of squares, were constructed according to the Central Composite Rotatable Design matrix generated (Table 1).

\subsection{Production of cottage cheese added with pequi oil}

Cottage cheese was manufactured using skim cow milk $(0.23 \%$ fat). Milk fat content was determined by Gerber method (Kleyn et al., 2001). The milk was heated to $85^{\circ} \mathrm{C}$ and lactic acid was added as coagulant (Rasheed et al., 2016). Thereafter, the mass was allowed to stand for 30 minutes and the curd was washed three times, with water at $20^{\circ} \mathrm{C}, 10{ }^{\circ} \mathrm{C}$ and $5^{\circ} \mathrm{C}$ for $20 \mathrm{~min}$ each, and drained through a fine cheese cloth. The dressing cream was prepared with skimmed and pasteurized milk, which was heated to $30^{\circ} \mathrm{C}$ and subjected to fermentation for 4 hours with 10\% lactic ferment (Lactococcus lactis subsp. Lactis and Lactococcus lactis subsp. Cremoris). The following ingredients were then added: emulsifier, consisting of xanthan

Table 1. Design matrix for Central Composite Rotatable Design.

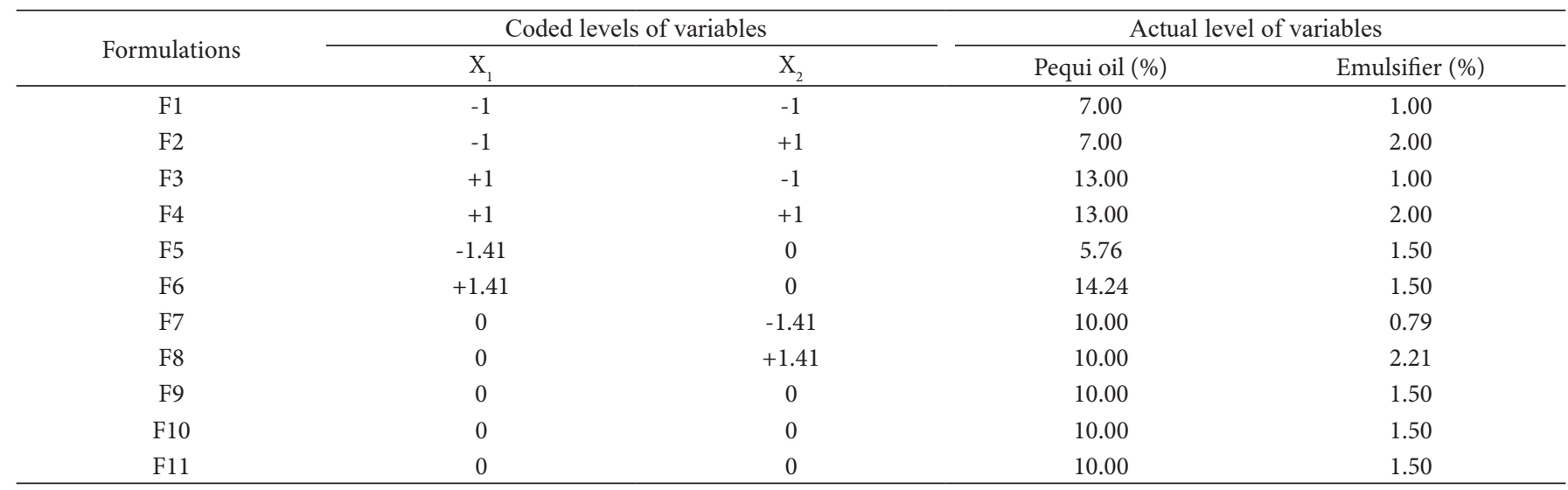


gum, guar gum and carrageenan (1 to $2 \%$ ), pequi pulp oil (7 to $13 \%)$, sodium chloride $(3.0 \%)$, and sorbate of potassium $(0.15 \%)$. The dressing was mixed with the cheese curd and then pasteurized and cooled $\left(5^{\circ} \mathrm{C}\right)$.

\subsection{Physicochemical analyses of formulations}

The formulations were analyzed for moisture, protein, fat, $\mathrm{pH}$, and acidity in lactic acid according to the AOAC (Association of Official Analytical Chemists, 2006) [934.01 and 984.13, respectively]. The color was measured using a chromameter CR300 colorimeter (Minolta Co., Osaka, Japan) and the $L^{*}, a^{*}$ and $\mathrm{b}^{\star}$ parameters were determined according to the International Commission on Illumination (Commission Internationale de L’Eclairage, 1986).

\subsection{Textural properties of formulations}

Textural properties were analyzed in a texturometer model TA-XT2i Texture AnalyzerTM (Stable Microsystems, Haslemere, England) using the probe P/25 (compression board of $25 \mathrm{~mm}$ in diameter) speed of $5 \mathrm{~mm} \mathrm{~s}-1$, compression of $5 \mathrm{~mm}$ height, and time between the two compressions $5 \mathrm{~s}$. The samples were analyzed at $24{ }^{\circ} \mathrm{C}$ in quintuplicate (Kavak \& Karabiyik, 2020).

All data were expressed as mean values \pm standard deviation, $\mathrm{n}=3$. Statistical analysis was performed using ANOVA followed by Duncan's Multiple Range Test. Least significant differences were obtained using a least significant difference test $(\mathrm{p}<0.05)$.

\section{Results and discussion}

\subsection{Chemical and physicochemical properties of pequi pulp oil}

The physicochemical characteristics of pequi (Caryocar coreaceum) pulp oil extracted by a homemade method were presented in Table 2. Ours results showed that the pequi pulp oil exhibited a density similar to Soxhlet-extracted pequi pulp oil and higher than pequi pulp and alomond oil extracted by hydraulic pressing (Sena et al., 2010; Pereira et al., 2020; Lima et al., 2020). The acidity value in our study was of 1.67 $\pm 0.01 \mathrm{mg} \mathrm{KOH} \mathrm{g}^{-1}$, within the range (0.00-3.00 $\left.\mathrm{mg} \mathrm{KOH} \mathrm{g}^{-1}\right)$ recommended for human consumption and did not exceed $4 \mathrm{mg} \mathrm{KOH} \mathrm{g}^{-1}$, which is one of the main parameters used to indicate quality in edible oils (Food and Agriulture Organization, 2013; Alajtal et al., 2018). Peroxide value was similar to crude palm oil $\left(0.61 \pm 0.05 \mathrm{mEq} \mathrm{O}_{2} \mathrm{~kg}^{-1}\right.$ oil $)$, and lower than pequi pulp and almond oil extracted by hydraulic pressure (Pereira et al., 2020; Almeida et al., 2019; Lima et al., 2020). Peroxide values were between the range of $0-10 \mathrm{mEq} \mathrm{O}_{2} \mathrm{Kg}^{-1}$ oil, considered adequate for fresh oil (Food and Agriulture Organization, 2013).

Saponification value represents the number of milligrams of potassium hydroxide $(\mathrm{KOH})$ required to saponify one gram of fat and is a measure of the average molecular weight of the triglyceride. High and low saponification values indicate low and high molecular weights of the triglyceride, respectively (Omari et al., 2015). Pequi pulp oil presented a saponification value similar to palm oil $\left(200.05 \pm 0.42 \mathrm{mg} \mathrm{KOH} \mathrm{g}^{-1}\right)$ and pequi almond oil extracted by hydraulic pressure (Almeida et al.,

Table 2. Chemical characteristics and fatty acid composition of pequi (Caryocar coriaceum) pulp and almond oil.

\begin{tabular}{|c|c|c|c|c|c|}
\hline \multirow{3}{*}{ Chemical characteristics } & \multicolumn{5}{|c|}{ Caryocar coreaceum } \\
\hline & \multicolumn{3}{|c|}{ Pulp oil } & \multicolumn{2}{|c|}{ Almond oil } \\
\hline & $\begin{array}{c}\text { Homemade } \\
\text { method }\end{array}$ & Soxhlet extraction ${ }^{1}$ & Hydraulic pressing ${ }^{2}$ & Hydraulic pressing ${ }^{2}$ & Hydraulic pressing ${ }^{3}$ \\
\hline Acid value (mg KOH g ${ }^{-1}$ ) & $1.67 \pm 0.01$ & - & - & - & $0.17 \pm 0.02$ \\
\hline Density $\left(\mathrm{g} \mathrm{mL}^{-1}\right)$ & $0.91 \pm 0.01$ & $0.9082 \pm 0.0014$ & $0.30 \pm 0.35$ & $0.31 \pm 0.50$ & - \\
\hline Peroxide value $\left(\mathrm{mEq} \mathrm{kg}{ }^{-1}\right)$ & $0.63 \pm 0.00$ & - & $4.40 \pm 0.72$ & $5.60 \pm 0.72$ & $1.22 \pm 0.02$ \\
\hline Iodine value (g I2 $100 \mathrm{~g}^{-1}$ ) & $60.11 \pm 0.04$ & - & - & - & 54.13 \\
\hline Saponification value $\left(\mathrm{mg} \mathrm{KOH} \mathrm{g}^{-1}\right)$ & $200.55 \pm 1.34$ & - & - & - & 209.65 \\
\hline \multicolumn{6}{|l|}{ Fatty acids (\%) } \\
\hline Caproic acid (C6:0) & 0.02 & - & - & - & - \\
\hline Octanoic (C8:0) & 0.01 & - & - & - & - \\
\hline Myristic (C14:0) & 0.01 & - & - & - & $0.22 \pm 0.03$ \\
\hline Palmitic (C16:0) & 33.40 & 34.18 & 27.59 & 46.27 & $39.49 \pm 3.03$ \\
\hline Arachidic (C20:0) & 0.05 & - & - & - & - \\
\hline Palmitoleic (C16:1n7) & - & 0.27 & - & - & - \\
\hline Stearic (C18:0) & 2.87 & 1.73 & - & - & $1.63 \pm 0.13$ \\
\hline Oleic (C18:1n9c) & 62.61 & 55.79 & 72.41 & 48.09 & $42.47 \pm 2.11$ \\
\hline Linoleic (C18:2n6c) & 0.95 & 1.80 & - & 4.96 & $10.17 \pm 0.55$ \\
\hline Heptadecenoic (C17:1) & - & 5.86 & - & - & - \\
\hline Eicosenoic (C20:1) & - & 0.37 & - & - & - \\
\hline Heneicosanoic acid (C21:0) & - & - & - &. & 1.68 \\
\hline$\sum$ Saturated & 37.36 & - & 27.59 & 47.95 & 41.34 \\
\hline$\sum$ Unsaturated & 63.63 & - & 72.41 & 53.05 & 51.63 \\
\hline Not identified & - & - & - & - & 6.02 \\
\hline
\end{tabular}

${ }^{1}$ Sena et al., 2010. ${ }^{2}$ Pereira et al., 2019. ${ }^{3}$ Lima et al., 2020. 
2019; Lima et al., 2020). These results demonstrate the high proportion of low molecular weight fatty acids in the analyzed samples, further indicating the similarity between different oils analyzed in terms of fatty acid composition (Omari et al., 2015).

The iodine value of pequi pulp oil was higher than that of pequi almond oil extracted by hydraulic pressing and to that fresh palm oil ( $50.8 \pm 0.72 \mathrm{~g} \mathrm{I}_{2} 100 \mathrm{~g}^{-1}$ ) (Chebet et al., 2016; Lima et al., 2020 ). Since the iodine value is a measure of the unsaturation degree of the oil (Soares \& Rocha, 2018), this result sugested that pequi pulp oil contained a substantial amount of unsaturated fatty acids, which was confirmed by GC-MS (Table 2).

\subsection{Pequi pulp oil by gas chromatography coupled to mass spectrometry}

The total of unsaturated and saturated fatty acids from pequi pulp oil is demonstrated in Table 2. The value of the total unsaturated fatty acids presented in our pequi pulp oil is between the values obtained for olive oil (58.68\%) and sunflower oil (81.06\%), and higher than pequi almond oil extracted by hydraulic pressing and less than pequi pul oil extracted by hydraulic pressing (Ivanova et al., 2016; Pereira et al., 2020; Lima et al., 2020). Among these, monounsaturated oleic acid was the major component at $62.61 \%$ (Figure 1). Likewise, Sena et al. (2010), Pereira et al. (2020) and Lima et al. (2020) found that oleic acid was the main compound in pequi pulp and almond oil obtained by solvent extraction and by using hydraulic pressing. Interestingly, the total of content monounsaturated oleic acid found in pequi pulp oil is similar to that in olive oil at around 64.4\% (Ivanova et al., 2016). The similarity in the profile of fatty acids might suggest that pequi oil could present the same beneficial effects such as olive oil used in the Mediterranean diet (Visioli et al., 2018). This similarity of the chemical composition of pequi oil with olive oil, is gradually revealing itself as well as the similarities in biological activities. Recent research has demonstrated the beneficial properties of pequi (Caryocar) fruit

a)

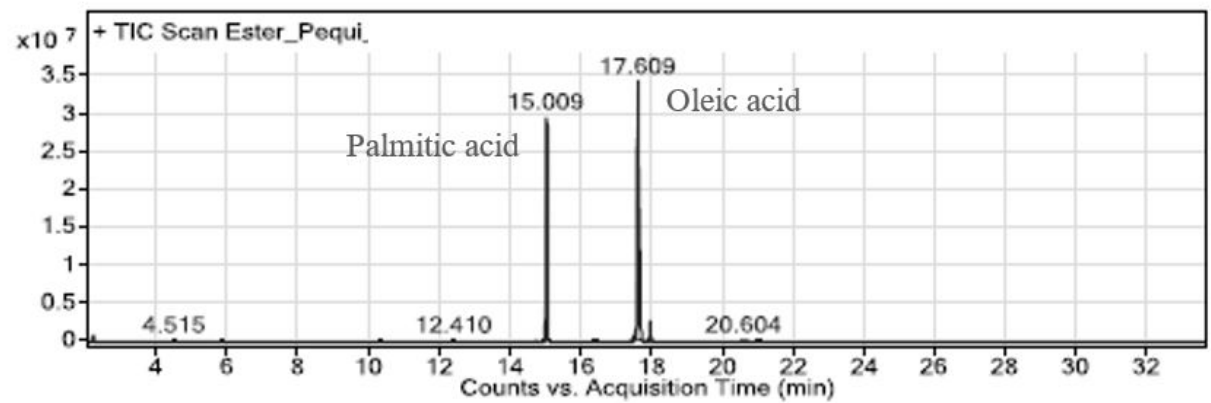

b)

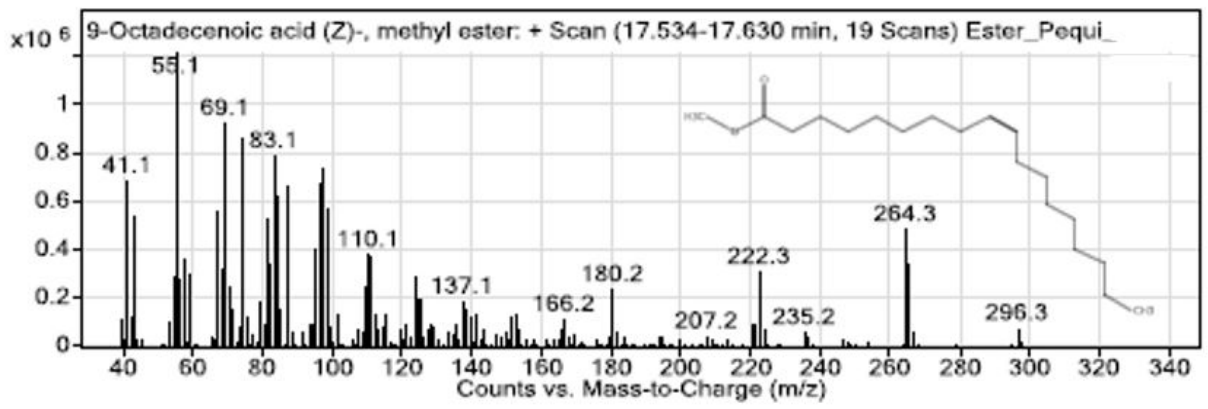

c)

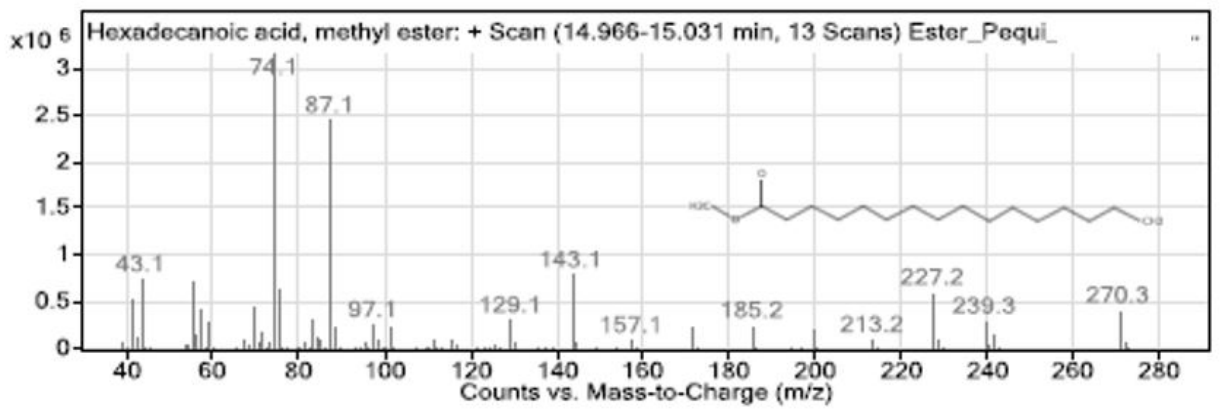

Figure 1. Chromatogram of major fatty acids found in pequi (Caryocar coriaceum) pulp oil (a). Mass spectrum of oleic acid (b) and palmitic acid (c). 
such as antioxidant, anti-inflammatory, antitumor, antimicrobial, cardioprotective and hypolipemic effects (Figueiredo et al., 2016; Torres et al., 2018).

Concerning saturated fatty acids, this group represented $37.36 \%$ of the total fatty acids, with palmitic acid being the main component (Figure 1), followed by stearic acid (2.87\%), and eicosanoic acid (Table 2). Similar results were demonstrated by others (Sena et al., 2010; Pererira et al., 2020; Lima et al., 2020 ). With respect to polyunsaturated fatty acids, pequi oil $(0.95 \%)$ showed lower amounts similar to olive oil (1.79\%) (Ivanova et al., 2016).

\subsection{Chemical and physicochemical properties of formulations}

The physicochemical properties of formulations are shown in Table 3. Ours results showed a significant difference $(\mathrm{p}<0.05)$ in fat content among the formulations, which was determined by the quantity of pequi pulp oil present in the cream dressing. As expected, concentrations of protein and moisture were inversely proportional to fat content. The addition of an emulsifier further augmented the moisture and protein levels, most likely due to its water retention properties (Murtaza et al., 2017). Similar results were reported by Nateghi et al. (2012b) and Murtaza et al. (2017), who demonstrated that the use of food gums increased the moisture and protein levels in cheddar cheese. Moisture is important for cheese as it contributes to softness and other quality characteristics and is bound to the protein to maintain elasticity of cheese (Murtaza et al., 2017).

The $\mathrm{pH}$ and acidity values were statistically different $(\mathrm{p}<0.05)$ among some formulations. Formulations F6 (P14.24\%+E1.5\%) and F8 (P10\%+E2.20\%), which contained the highest amounts of pequi oil and emulsifier, had significantly higher acidity values compared to other formulations. By increasing the pequi oil and emulsifier levels, the corresponding acidity and $\mathrm{pH}$ values increased and decreased. Murtaza et al. (2017) showed a reduction in acidity and an increase in $\mathrm{pH}$ in low-fat cheddar cheese produced with xanthan gum.
The color values of formulations are also presented in Table 3. According to the analyses, F3, F4 and F6, which contained the largest amounts of pequi pulp oil, presented the lowest values for $\mathrm{L}^{*}$, which indicates a darker coloration. For the coordinate $\mathrm{a}^{*}$, negative values close to zero were obtained in the analyses, indicating an approximation with the green tone, and F7 presented the lowest value for this coordinate $(\mathrm{p}<0.05)$. The results for the $b^{*}$ coordinate indicates greater proximity to yellow color. The highest chroma $b^{*}$ values were obtained for F3, F4, and F6, which had the highest concentration of pequi pulp oil. It is believed that the predominance of the yellow color found in cheese samples containing more pequi pulp oil is caused by the presence of carotenoids, giving a yellowish color (Silva \& Fonseca, 2016).

\subsection{Textural attributes}

The texture of cheese is the combination of different parameters, including cohesiveness, adhesiveness, gumminess, chewiness, springiness, and hardness that play a role in the quality and consumer acceptance. In the present study, the influence of pequi oil and emulsifier on textural properties of cottage cheese was investigated, considering previous studies, which have shown that fats and emulsifiers are important factors in textural properties of cheese (Nateghi et al., 2012a; Nateghi et al., 2012b; Cankurt, 2019). A decrease in both fats and emulsifiers produces changes in physical properties, which results in decreased cheese flavor and quality (Nateghi et al., 2012a; Nateghi et al., 2012b; Cankurt, 2019).

Table 4 presents the results obtained from the instrumental texture evaluation. According to the results, cohesiveness between F10 (P10\% + E1.5\%) and F8 (P10\% + E2.2\%) and in springiness between F7 (P10\% + E0.79\%) and F9, F10, and F11 $(\mathrm{P} 10 \%+\mathrm{E} 1.50 \%)$ formulations were significantly reduced, with increasing emulsifier concentration. Similarly, when comparing F7 (P10\% + E0.79\%) with F8 (P10\% + E2.20\%), it was observed that increasing the emulsifier concentration reduced the adhesiveness, gumminess, chewiness, and hardness values. The formulation F7, which was produced with the lowest emulsifier concentration $(0.79 \%)$, had the lowest value for adhesiveness

Table 3. Chemical, physicochemical analysis and color measurements of formulations added with pequi (Caryocar coriaceum) pulp oil.

\begin{tabular}{|c|c|c|c|c|c|c|c|c|}
\hline \multirow[b]{2}{*}{ Formulations (F) } & Fat & Protein & Moisture & \multirow[b]{2}{*}{$\mathrm{pH}$} & \multirow{2}{*}{$\begin{array}{c}\text { Acidity } \\
\text { (latic acid g } \\
\left.100 \mathrm{~g}^{-1}\right)\end{array}$} & \multicolumn{3}{|c|}{ Color } \\
\hline & $(\%)$ & $(\%)$ & $(\%)$ & & & $\mathrm{L}^{*}$ & $a^{*}$ & $b^{*}$ \\
\hline F1:P7\%+E1\% & $7.48 \pm 0.01 \mathrm{~d}$ & $19.70 \pm 0.34 \mathrm{a}$ & $68.93 \pm 0.24 c$ & $4.73 \pm 0.08 c$ & $0.27 \pm 0.00 \mathrm{bc}$ & $86.34 \pm 0.04 c d$ & $-4.16 \pm 0.01 b$ & $23.23 \pm 0.03 \mathrm{cdf}$ \\
\hline F2:P7\%+E2\% & $7.58 \pm 0.01 \mathrm{~d}$ & $21.02 \pm 1.71 \mathrm{a}$ & $65.18 \pm 0.47 \mathrm{a}$ & $4.74 \pm 0.01 c e$ & $0.27 \pm 0.01 b c$ & $85.65 \pm 0.01 \mathrm{ef}$ & $-4.45 \pm 0.01 d$ & $25.97 \pm 2.87 \mathrm{be}$ \\
\hline F3:P13\%+E1\% & $13.33 \pm 0.20 c$ & $18.81 \pm 1.02 \mathrm{a}$ & $62.44 \pm 0.31 f$ & $4.64 \pm 0.02 \mathrm{~d}$ & $0.27 \pm 0.01 b c$ & $85.14 \pm 0.06 \mathrm{a}$ & $-4.23 \pm 0.03 b$ & $27.73 \pm 0.05 \mathrm{ab}$ \\
\hline F4:P13\%+E2\% & $13.16 \pm 0.03 c$ & $20.61 \pm 1.69 a$ & $61.94 \pm 0.11 \mathrm{ef}$ & $4.76 \pm 0.01 c e$ & $0.27 \pm 0,00 \mathrm{bc}$ & $84.44 \pm 0.10 \mathrm{~b}$ & $-4.30 \pm 0.01 \mathrm{efg}$ & $28.72 \pm 0.01 \mathrm{a}$ \\
\hline F5:P5.75\%+E1.5\% & $5.66 \pm 0.03 b$ & $21.26 \pm 0.78 a$ & $68.18 \pm 0.06 c$ & $4.63 \pm 0.04 \mathrm{~d}$ & $0.22 \pm 0.04 c$ & $86.54 \pm 0.07 c$ & $-4.26 \pm 0.02 \mathrm{bef}$ & $22.28 \pm 0.08 \mathrm{~cd}$ \\
\hline F6:P14.24\%+E1.5\% & $14.35 \pm 0.08 \mathrm{a}$ & $19.53 \pm 0.91 \mathrm{a}$ & $61.17 \pm 0.55 \mathrm{e}$ & $4.76 \pm 0.02 c$ & $0.31 \pm 0.01 \mathrm{ab}$ & $85.46 \pm 0.06 f$ & $-4.34 \pm 0.01 \mathrm{defg}$ & $29.23 \pm 0.07 a$ \\
\hline F7:P10\%+E0.79\% & $10.46 \pm 0.46 f$ & $18.48 \pm 0.90 a$ & $62.39 \pm 0.32 \mathrm{f}$ & $4.71 \pm 0.01 \mathrm{de}$ & $0.26 \pm 0.02 b c$ & $86.22 \pm 0.03 \mathrm{~d}$ & $-3.57 \pm 0.09 a$ & $22.01 \pm 0.28 \mathrm{~d}$ \\
\hline F8:P10\%+E2.20\% & $10.09 \pm 0.03 \mathrm{f}$ & $18.80 \pm 1.38 \mathrm{a}$ & $66.54 \pm 0.24 \mathrm{~d}$ & $4.67 \pm 0.02 \mathrm{~d}$ & $0.35 \pm 0.01 \mathrm{a}$ & $85.66 \pm 0.13 e$ & $-4.41 \pm 0.03 \mathrm{dg}$ & $25.62 \pm 0.93$ bef \\
\hline F9:P10\%+E1.5\% & $10.46 \pm 0.40 \mathrm{f}$ & $18.56 \pm 0.72 \mathrm{a}$ & $66.47 \pm 0.46 \mathrm{~d}$ & $4.82 \pm 0.05 c$ & $0.25 \pm 0.02 b c$ & $87.10 \pm 0.05 g$ & $-4.48 \pm 0.04 c$ & $24.72 \pm 0.17$ cef \\
\hline F10:P10\%+E1.5\% & $10.47 \pm 0.37 f$ & $18.58 \pm 0.49 a$ & $61.92 \pm 0.19 \mathrm{ef}$ & $4.87 \pm 0,02 \mathrm{a}$ & $0.25 \pm 0.03 \mathrm{bc}$ & $87.29 \pm 0.07 \mathrm{~g}$ & $-4.31 \pm 0.04 \mathrm{efg}$ & $24.41 \pm 0.06 \mathrm{cdef}$ \\
\hline F11:P10\%+E1.5\% & $10.88 \pm 0.03 \mathrm{f}$ & $18.75 \pm 0.34 \mathrm{a}$ & $64.06 \pm 0.01 \mathrm{~b}$ & $4.87 \pm 0.01 \mathrm{a}$ & $0.27 \pm 0.01 b c$ & $87.09 \pm 0.03 \mathrm{~g}$ & $-4.35 \pm 0.05 \mathrm{dfg}$ & $25.09 \pm 0.13 \mathrm{bef}$ \\
\hline
\end{tabular}

P: Pequi pulp oil; E: Emulsifier; $L^{*}$, lightness; $a^{*}$, redness; $b^{*}$, yellowness. The values were presented as Mean \pm Standard Deviation (SD), $\mathrm{n}=3$. Means values in the same column with different letters are significantly different $\left({ }^{*} \mathrm{p}<0.05\right)$. 
Table 4. Textural characteristics of formulations added with pequi (Caryocar coriaceum) pulp oil.

\begin{tabular}{lcccccc}
\hline Formulations (F) & Cohesiveness & Springiness & Adhesiveness (gfs) & Gumminess (gf) & Chewiness & Hardness (gf) \\
\hline F1:P7\%+E1\% & $0.513 \pm 0.04 \mathrm{ab}$ & $0.95 \pm 0.03 \mathrm{~d}$ & $-28.65 \pm 3.81 \mathrm{~cd}$ & $188.07 \pm 14.14 \mathrm{bcd}$ & $178.14 \pm 6.93 \mathrm{bcd}$ & $388.20 \pm 30.08 \mathrm{bc}$ \\
F2:P7\%+E2\% & $0.593 \pm 0.01 \mathrm{bcde}$ & $0.93 \pm 0.01 \mathrm{~cd}$ & $-99.70 \pm 18.00 \mathrm{a}$ & $363.21 \pm 52.61 \mathrm{efg}$ & $337.70 \pm 46.71 \mathrm{ef}$ & $611.58 \pm 82.19 \mathrm{f}$ \\
F3:P13\%+E1\% & $0.487 \pm 0.05 \mathrm{abc}$ & $0.85 \pm 0.05 \mathrm{bc}$ & $-56.79 \pm 2.78 \mathrm{bc}$ & $217.10 \pm 41.79 \mathrm{cde}$ & $182.49 \pm 4.94 \mathrm{bcd}$ & $442.45 \pm 43.11 \mathrm{bcde}$ \\
F4:P13\%+E2\% & $0.466 \pm 0.04 \mathrm{a}$ & $0.90 \pm 0.02 \mathrm{bcd}$ & $-122.06 \pm 31.35 \mathrm{a}$ & $140.72 \pm 15.54 \mathrm{abc}$ & $126.11 \pm 3.66 \mathrm{abc}$ & $301.68 \pm 14.37 \mathrm{~b}$ \\
F5:P5.75\%+E1.5\% & $0.540 \pm 0.06 \mathrm{abc}$ & $0.89 \pm 0.00 \mathrm{bcd}$ & $-47.88 \pm 5.99 \mathrm{bc}$ & $233.16 \pm 44.91 \mathrm{cde}$ & $206.95 \pm 0.62 \mathrm{cde}$ & $455.00 \pm 7.25 \mathrm{bcdef}$ \\
F6:P14.24\%+E1.5\% & $0.511 \pm 0.04 \mathrm{abcd}$ & $0.82 \pm 0.02 \mathrm{ab}$ & $-58.10 \pm 0.93 \mathrm{bc}$ & $291.36 \pm 53.09 \mathrm{def}$ & $238.84 \pm 9.62 \mathrm{cdef}$ & $537.22 \pm 70.10 \mathrm{cdef}$ \\
F7:P10\%+E0.79\% & $0.595 \pm 0.06 \mathrm{cde}$ & $0.94 \pm 0.05 \mathrm{~d}$ & $-11.58 \pm 7.00 \mathrm{~d}$ & $712.32 \pm 137.61 \mathrm{~h}$ & $670.39 \pm 49.24 \mathrm{~g}$ & $915.95 \pm 126.41 \mathrm{~g}$ \\
F8:P10\%+E2.20\% & $0.562 \pm 0.03 \mathrm{abcd}$ & $0.95 \pm 0.00 \mathrm{~d}$ & $-50.75 \pm 3.40 \mathrm{bc}$ & $223.53 \pm 9.34 \mathrm{cde}$ & $213.33 \pm 9.05 \mathrm{cde}$ & $398.11 \pm 3.01 \mathrm{bcd}$ \\
F9:P10\%+E1.5\% & $0.633 \pm 0.02 \mathrm{de}$ & $0.75 \pm 0.03 \mathrm{a}$ & $-48.29 \pm 6.61 \mathrm{bc}$ & $404.45 \pm 38.69 \mathrm{fg}$ & $304.11 \pm 1.74 \mathrm{def}$ & $551.51 \pm 36.36 \mathrm{def}$ \\
F10:P10\%+E1.5\% & $0.675 \pm 0.01 \mathrm{e}$ & $0.85 \pm 0.06 \mathrm{bc}$ & $-57.73 \pm 2.48 \mathrm{bc}$ & $447.73 \pm 27.84 \mathrm{~g}$ & $380.83 \pm 36.09 \mathrm{f}$ & $570.01 \pm 31.70 \mathrm{ef}$ \\
F11:P10\%+E1.5\% & $0.641 \pm 0.02 \mathrm{de}$ & $0.84 \pm 0.03 \mathrm{~b}$ & $-63.89 \pm 6.94 \mathrm{~b}$ & $357.12 \pm 23.22 \mathrm{efg}$ & $299.20 \pm 15.85 \mathrm{def}$ & $474.83 \pm 21.03 \mathrm{cdef}$ \\
\hline
\end{tabular}

P: Pequi oil; E: Emulsifier; $L^{*}$, lightness; $a^{*}$, redness; $b$, yellowness. The values were presented as Mean \pm Standard Deviation (SD), $\mathrm{n}=3$. Means values in the same column with different letters are significantly different $\left({ }^{*} \mathrm{p}<0.05\right)$.

$(-11.58 \mathrm{~g})$ and the highest values for gumminess (712.32 gf), chewiness (670.39), and hardness (915.95 gf). These differences in textural properties were expected and could be explained by differences in concentrations of emulsifiers used, since they consist of a mixture of hydrocolloid gums (xanthan gum, guar gum, and carrageenan), which are carbohydrate-based fat substitutes with the ability to control the rheology of water-based systems and to inhibit syneresis (Murtaza et al., 2017). Declined adhesiveness, gumminess, chewiness, and hardness values with increased concentration of emulsifier might be due to increased water retention (Murtaza et al., 2017). The addition of gums to low-fat cheese softens the structure by interfering with caseincasein interactions and cellulose particles that function similarly to fat globules. Similar results were observed for low-fat cheddar cheese, where hardness, gumminess, and chewiness of low-fat samples with added hydrocolloids, reduced gradually with the concentration of gums (Murtaza et al., 2017).

Pequi oil, when added at higher concentrations, promoted a significant reduction in both cohesiveness and springiness, which can be seen as an example of formulations F1 (P7\% + $\mathrm{E} 1 \%)$ and $\mathrm{F} 3(\mathrm{P} 13 \%+\mathrm{E} 1 \%)$, and F2 (P7\% + E2\%) and F4 (P13\% $+\mathrm{E} 2 \%)$. Additionally, the results demonstrated that the increase in pequi oil concentration, as observed in the formulations containing 7\% (F2), 10\% (F8), and 13\% (F4), promoted a significant reduction depending on the concentration of oil in cohesiveness (F2 0.593, F8 0.562, and F4 0.466), gumminess (F2 363.21gf, F8 223.53gf, and F4 140.72gf), chewiness (F2 337.70, F8 213.33, and F4 126.11), and hardness (F2 611.58gf, F8 398.11gf, and F4 301.68gf). Similar results were obtained by Nateghi et al. (2012b), who showed that fat reduction led to an increase in the cohesiveness, hardness, and springiness of fresh cheddar cheese. Low-and reduced-fat cheese exhibits poor texture and body compared to full-fat cheese due to the increased hardness, gumminess, springiness, and chewiness of the cheese (Delgado et al., 2011, Nateghi et al., 2012a).

\section{Conclusion}

In conclusion, the present work demonstrates the possibility of producing cottage cheese with the addition of pequi oil. Both pequi pulp oil and emulsifier positively influenced physicochemical and sensory characteristics of the cheese, as they improved the texture and body by decreasing cohesiveness, hardness, gumminess, springiness, and chewiness of the cheese. The production of a new cheese added with pequi pulp oil is a viable alternative for the use and valorization of pequi, as well as bringing the possibility of practical application of an oil with beneficial health properties, due in part to the presence of high levels of oleic acid and carotenoids.

\section{Acknowledgements}

The authors thank the CAPES for the master scholarship granted for the first author.

\section{References}

Adams, R. P. (2007). Identification of essential oil components by gas chromatography/ mass spectrometry (4th ed.). Carol Stream: Allured.

Aini, N., Sumarmono, J., Sustriawan, B., Prihananto, V., \& Priscillia, E. (2020). The quality of corn milk-based cheese analogue made with virgin coconut oil as a fat substitute and with various emulsifiers. In B. Nurhadi (Ed.), IOP Conference Series: Earth and Environmental Science. Vancouver: IOP Conference Series: Earth and Environmental Science. http://dx.doi.org/10.1088/1755-1315/443/1/012039

Alajtal, A. I., Sherami, F. E., \& Elbagermi, M. A. (2018). Acid, peroxide, ester and saponification values for some vegetable oils before and after frying. AASCIT Journal of Materials, 4, 43-47.

Al-Ismail, K., Al-Hiary, B., \& Al-Dabbas, M. (2015). Evaluation of some chemical and sensory properties of processed cheese analogue with selected vegetable oils. International Journal of Chemical and Process Engineering Research, 2(6), 75-85. http://dx.doi.org/10.18488/ journal.65/2015.2.6/65.6.75.85.

Almeida, D. T., Viana, T. V., Costa, M. M., Silva, C. S., \& Feitosa, S. (2019). Effects of different storage conditions on the oxidative stability of crude and refined palm oil, olein and stearin (Elaeis guineensis). Food Science and Technology, 39(Suppl. 1), 211-217. http://dx.doi. org/10.1590/fst.43317.

Association of Official Analytical Chemists - AOAC. (1999). Official methods of analysis (16th ed.). Gaithersburg: AOAC.

Association of Official Analytical Chemists - AOAC. (2006). Official methods of analysis (18th ed.). Gaithersburg: AOAC.

Bielecka, M., \& Cichosz, G. (2020). The effect of milk fat replacement and the addition of Lactobacillus paracasei LPC-37 on the sensory 
properties of cheeses. Mljekarstvo, 70(1), 28-39. http://dx.doi. org/10.15567/mljekarstvo.2020.0103.

Cankurt, H. (2019). The effects of adding different stabilizers in brine on the physicochemical, sensory, microbiological and textural properties of white cheese. Foods, 8(4), 133. http://dx.doi.org/10.3390/ foods8040133. PMid:31010198.

Castillo, M. D., Iriondo-Dehond, A., \& Martirosyan, D. M. (2018). Are functional foods essential for sustainable health? Annals of Nutrition \& Food Science, 2(1), 1-4.

Chebet, J., Kinyanjui, T., \& Cheplogo, P. K. (2016). Impact of frying on iodine value of vegetable oils before and after deep frying in different types of food in Kenya. Journal of Scientific and Innovative Research, 5, 193-196.

Commission Internationale de L'Eclairage - CIE. (1986). Colorimetry (4th ed.), Vienna: CIE. https://doi.org/10.25039/TR.015.2018

Delgado, J. F., Gonzalez-Crespo, J., Cava, R., \& Ramırez, R. (2011). Proteolysis, texture and colour of a raw goat milk cheese throughout the maturation. European Food Research and Technology, 233(3), 483-488. http://dx.doi.org/10.1007/s00217-011-1536-3.

Figueiredo, P. R. L., Oliveira, I. B., Neto, J. B. S., Oliveira, J. A., Ribeiro, L. B., Viana, G. S. B., Rocha, T. M., Leal, L. K. A. M., Kerntopf, M. R., Felipe, C. F. B., Coutinho, H. D. M., \& Menezes, I. R. A. (2016). Caryocar coriaceum Wittm. (Pequi) fixed oil presents hypolipemic and anti-inflammatory effects in vivo and in vitro. Journal of Ethnopharmacology, 191, 87-94. http://dx.doi.org/10.1016/j. jep.2016.06.038. PMid:27321275.

Food and Agriulture Organization - FAO. (2013). Codex standard for named vegetable oils: Codex-Stan 210. Rome: FAO/WHO.

Food and Agriculture Organization - FAO. (2019). OECD-FAOAgricultural Outlook : 2010-2019 (pp. 180-189). Chapter 7: Dairy and dairy products. Paris: OECD.

Górska-Warsewicz, H., Rejman, K., Laskowski, W., \& Czeczotko, M. (2019). Milk and dairy products and their nutritional contribution to the average polish diet. Nutrients, 11(8), 1771. http://dx.doi. org/10.3390/nu11081771. PMid:31374893.

Guedes, A. M. M., Antoniassi, R., \& Faria-Machado, A. F. (2017). Pequi: a Brazilian fruit with potential uses for the fat industry. Oilseeds \& fats Crops and Lipids, 24(5), D507. http://dx.doi.org/10.1051/ ocl/2017040.

International Union of Pure and Applied Chemistry - IUPAC. (1979). Standard methods for the analysis of oils, fats and derivatives (6th ed.) Oxford: Pergamon Press.

Ivanova, S., Marinova, G., \& Batchvarov, V. (2016). Comparison of fatty acid composition of various types of edible oils. Bulgarian Journal of Agricultural Science, 22(5), 849-856.

Kavak, D. D., \& Karabiyik, H. (2020). Quality evaluation of kashar cheese: influence of palm oil and ripening period. Food Science and Technology, 40(2), 354-360. http://dx.doi.org/10.1590/fst.39618.

Kleyn, D. H., Lynch, J. M., Barbano, D. M., Bloom, M. J., Mitchell, M. W., Cooper, L. S., Cusak, E., Fick, M., Hanks, T., Hesen, M. K., Johnson, J., Kleyn, D. H., Mercer, F., Monahan, D., Peat, B., \& Petit, M. (2001). Determination of fat in raw and processed milks by the gerber method: collaborative study. Journal of AOAC International, 84(5), 1499-1508. http://dx.doi.org/10.1093/jaoac/84.5.1499.

Lima, J. R., Souza, A. C. R., Magalhães, H. C. R., \& Pinto, C. O. (2020). Pequi kernel oil extraction by hydraulic pressing and its characterization. Revista Brasileira de Fruticultura, 42(5), e-456. http://dx.doi.org/10.1590/0100-29452020456.

Lobato-Calleros, C., Reyes-Hernandez, J., Beristain, I. C., HornelasUribe, Y., Sanchez-Garcia, J. E., \& Vernon-Carter, E. J. (2007).
Microstructure and texture of white fresh cheese made with canola oil and whey protein concentrate in partial or total replacement of milk fat. Food Research International, 40(4), 529-537. http://dx.doi. org/10.1016/j.foodres.2006.10.011.

Murtaza, M. S., Sameen, A., Huma, N., \& Hussain, F. (2017). Influence of hydrocolloid gums on textural, functional and sensory properties of low fat cheddar cheese from buffalo milk. Pakistan Journal of Zoology, 49(1), 27-34. http://dx.doi.org/10.17582/journal.pjz/2017.49.1.27.34.

Nateghi, L., Roohinejad, S., Totosaus, A., Mirhosseini, H., Shuhaimi, M., Meimandipour, A., Omidizadeh, A., \& Manap, M. Y. A. (2012a). Optimization of textural properties and formulation of reduced fat Cheddar cheeses containing fat replacers. Journal of Food Agriculture and Environment, 10(2), 46-54.

Nateghi, L., Roohinejad, S., Totosaus, A., Rahmani, A., Tajabadi, N., Meimandipour, A., Rasti, B., \& Manap, M. Y. A. (2012b). Physicochemical and textural properties of reduced fat Cheddar cheese formulated with xanthan gum and/or sodium caseinate as fat replacers. Journal of Food Agriculture and Environment, 10(2), 59-63.

NIST Chemistry Webbook. (2011). Base de dados de Referência padrão do NIST número 69. Retrieved from http://webbook.nist.gov/chemistry.

Omari, A., Mgani, Q. A., \& Mubofu, E. B. (2015). Fatty acid profile and physico-chemical parameters of castor oils in Tanzania. Green and Sustainable Chemistry, 5(4), 154-163. http://dx.doi.org/10.4236/ gsc.2015.54019.

Pereira, F. F. G., Feitosa, M. K. S. B., Costa, M. S., Tintino, S. R., Rodrigues, F. F. G., Menezes, I. R. A., Coutinho, H. D. M., Costa, J. G. M., \& Sousa, E. O. (2020). Characterization, antibacterial activity and antibiotic modifying action of the Caryocar coriaceum Wittm. pulp and almond fixed oil. Natural Product Research.34(22), 3239-3243. http://dx.doi.org/10.1080/14786419.2018.1552955. PMid:30663376.

Rasheed, S., Qazi, I. M., Ahmed, I., Durrani, Y., \& Azma, Z. (2016). Comparative study of cottage cheese prepared from various sources of milk. Proceedings of the Pakistan Academy of Sciences, 53(4), 269-282.

Sena, D. M. Jr., Rodrigues, F. F. G., Freire, P. T. C., Lima, S. G., Coutinho, H. D. M., Carvajal, J. C. L., \& Costa, J. G. M. (2010). Physicochemical and spectroscopical investigation of pequi (Caryocar coriaceum Wittm.) pulp oil. Grasas y Aceites, 61(2), 191-196. http://dx.doi. org/10.3989/gya.105909.

Silva, C. A. A., \& Fonseca, G. G. (2016). Brazilian savannah fruits: characteristics, properties, and potential applications. Food Science and Biotechnology, 25(5), 1225-1232. http://dx.doi.org/10.1007/ s10068-016-0195-3. PMid:30263399.

Silva, L. H. P., Pinto, L. C. L., Teixeira, S. A. M., \& Drumond, M. A. (2020). Pequi fruit (Caryocar brasiliense) in Minas Gerais: commercialization and public policy. Floresta e Ambiente, 27(2), e20171129. http:// dx.doi.org/10.1590/2179-8087.112917.

Soares, S., \& Rocha, F. R. P. (2018). Fast spectrophotometric determination of iodine value in biodiesel and vegetable oils. Journal of the Brazilian Chemical Society, 29(8), 1701-1706. http://dx.doi.org/10.21577/01035053.20180044.

Torres, R. O., Santana, F. C., Shinagawa, F. B., \& Mancini-Filho, J. (2018). Bioactive compounds and functional potential of pequi (Caryocar spp.), a native Brazilian fruit: a review. Grasas y Aceites, 69(2), e257. http://dx.doi.org/10.3989/gya.1222172.

Vale, A. F., Ferreira, H. H., Benetti, E. J., Rebelo, A. C. S., Figueiredo, A. C. R., Barbosa, E. C., \& Simões, K. (2019). Antioxidant effect of the pequi oil (Caryocar brasiliense) on the hepatic tissue of rats trained by exhaustive swimming exercises. Brazilian Journal of Biology = Revista Brasileira de Biologia, 79(2), 257-262. http://dx.doi. org/10.1590/1519-6984.180015. PMid:30088525. 
Visioli, F., Franco, M., Toledo, E., Luchsinger, J., Willett, W. C., Hu, F. B., \& Martinez-Gonzalez, M. A. (2018). Olive oil and prevention of chronic diseases: summary of an International conference. Nutrition, Metabolism, and Cardiovascular Diseases, 28(7), 649-656. http:// dx.doi.org/10.1016/j.numecd.2018.04.004. PMid:29804831.
Wood, L. 2020. The global cheese market: trends, share, size, growth, opportunity and forecast 2020-2025. Retrieved from https://www. businesswire.com/news/home/20200407005667/en/The-GlobalCheese-Market-Trends-Share-Size-Growth-Opportunity-andForecast-2020-2025---ResearchAndMarkets.com. 